\title{
Dictynna
}

Dictynna

Revue de poétique latine

$5 \mid 2008$

Varia

\section{Tityrus and Galatea (Virgil, Eclogue 1): An Expected Relationship}

Michael Paschalis

\section{Q OpenEdition \\ 12 Journals}

\section{Electronic version}

URL: http://journals.openedition.org/dictynna/401

DOI: 10.4000/dictynna.401

ISSN: 1765-3142

\section{Electronic reference}

Michael Paschalis, «Tityrus and Galatea (Virgil, Eclogue 1): An Expected Relationship », Dictynna [Online], 5 | 2008, Online since 25 November 2010, connection on 10 September 2020. URL : http:// journals.openedition.org/dictynna/401; DOI : https://doi.org/10.4000/dictynna.401

This text was automatically generated on 10 September 2020 .

\section{(c) (i) (9)}

Les contenus des la revue Dictynna sont mis à disposition selon les termes de la Licence Creative Commons Attribution - Pas d'Utilisation Commerciale - Pas de Modification 4.0 International. 


\title{
Tityrus and Galatea (Virgil, Eclogue 1): An Expected Relationship
}

\author{
Michael Paschalis
}

\section{Introduction}

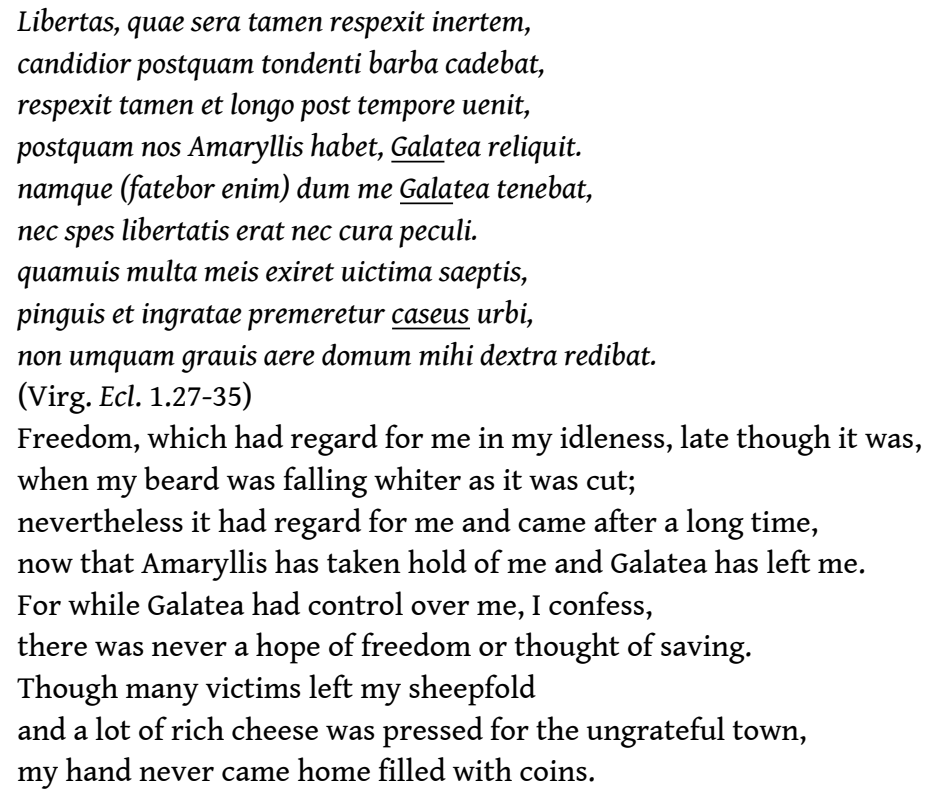

Libertas, quae sera tamen respexit inertem, candidior postquam tondenti barba cadebat, respexit tamen et longo post tempore uenit, postquam nos Amaryllis habet, Galatea reliquit. namque (fatebor enim) dum me Galatea tenebat, nec spes libertatis erat nec cura peculi. quamuis multa meis exiret uictima saeptis, pinguis et ingratae premeretur caseus urbi, non umquam grauis aere domum mihi dextra redibat.

(Virg. Ecl. 1.27-35)

Freedom, which had regard for me in my idleness, late though it was, when my beard was falling whiter as it was cut; nevertheless it had regard for me and came after a long time, now that Amaryllis has taken hold of me and Galatea has left me. For while Galatea had control over me, I confess, there was never a hope of freedom or thought of saving. Though many victims left my sheepfold and a lot of rich cheese was pressed for the ungrateful town, my hand never came home filled with coins.

1 In these lines of Eclogue 1 Tityrus explains to Meliboeus that in the past he had been unable to buy his freedom and that he managed to do so only now that he became an older man. One reason for the delay was the extravagance of Galatea, his former companion. Another was the ungrateful townspeople who paid him too little for the animals and the cheese he sold them. My starting point for re-examining these lines was the association between Galatea and caseus ('cheese') which I had noted in passing elsewhere. ${ }^{1}$ The 'white' beauty of 'milky' Galatea acquired fame in ancient literature thanks to the compliment which the Cyclops Polyphemus pays to her in Theocr. Id. 
11.19-20. In the Virgilian passage there is no reference to Galatea's beauty but, as I argue below, in other passages of Theocritus 11 the name suggests 'milk' without pointing to 'whiteness'. Another thing that struck me is that in Virgil's Eclogues it is only Tityrus that makes cheese. This is remarkable also because cheese-making is not an activity frequently mentioned in Augustan poetry and in addition the noun caseus is rare in verse. ${ }^{2}$ It is worthy of note that in adapting Theocritus 11 in Eclogue 2 Virgil conspicuously avoids the mention of cheese. In the Theocritean Idyll the Cyclops boasts to Galatea of his herd of a thousand cattle, the fine milk he produces from them, and his constant supply of cheese in summer, autumn and winter (11.34-37); but in Ecl. 2.19-22 Corydon proudly talks of his thousand female lambs and the constant supply of milk in summer and winter. ${ }^{3}$ Is it a mere coincidence that in the Eclogues only Tityrus boasts of having an abundant supply of cheese (pressi copia lactis, 1.81), in what is apparently a re-writing of the above-mentioned Theocritean passage? A third point is that in ancient bucolic and other pastoral literature Tityrus and Galatea form a pair only in this passage. In the subtle literary world of the Eclogues these details could be significant. Therefore I decided to explore further the semantic relationship between 'Tityrus' and 'Galatea'.

2 Several meanings of Títupos / títupos have come down to us. Most of them are conveniently collected in $\Sigma$ Theocr. Id. 3.2 Wendel: "It is said that the Siceliots call so

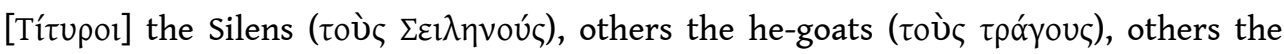

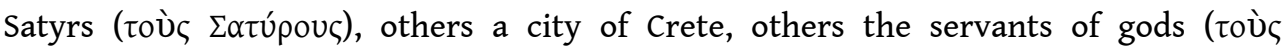

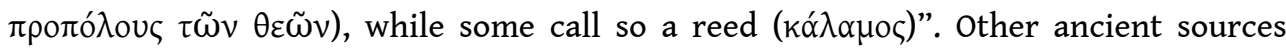

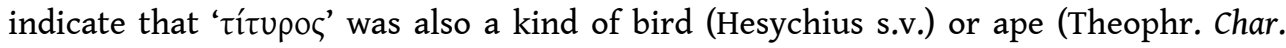
5.9). ${ }^{4}$

3 Attention to the meaning 'reed' or 'pipe ${ }^{5}$ was recently drawn by Francis Cairns. He reiterated the view that avena in Virg. Ecl. 1.2 may point to it and, combining literary evidence from other sources, argued that the opening lines characterize Virgil's work as "Italian Doric" and thus "signal Virgil's Theocritean programme". The article provoked an illuminating reaction by John Van Sickle. ${ }^{6}$

Virgilian scholars have repeatedly noted the sounds of 'Tityrus' in the opening lines, with or without reference to the meaning 'pipe' of ' $\tau i$ ívpos'. It is what Coleman calls the "suggestion of piping" in 'Tityre, $t u$... tu, Tityre', who also compares the repetition of $i$ and $u$ in Th. Id. 1.1-3 and 7.88-89. Wright believes that these sounds must have been "the crucial motivation for the choice of Tityrus" and, following Smith, points out the "happy conceit to have the shepherd playing his eponymous instrument". The probable onomatopoeic character of 'Tityrus' in these lines has a parallel in the etymology of Títupoifound in Aelian, VH 3.40. He reports that "the Satyroi, Dionysus' dancing companions, were by some called Títupor, a name derived ó $\pi$ ò $\tau \tilde{\omega} v$ $\tau \varepsilon \rho \varepsilon \tau 1 \sigma \mu \alpha$ ' $\tau \omega v$ ('from the trills') which the Satyrs enjoy". In addition to the linkage of Virgil's 'Tityrus' with the meaning 'reed' ('pipe') in the opening lines of Eclogue 1, other recorded meanings have been associated with the text of the Eclogues. For instance, Cairns believes that Ecl. 1.12-13 and 9.24-25 suggest the meaning 'he-goat', and that Ecl. 1.17-18 may allude to 'Tityrus' as 'an attendant of the gods'. ${ }^{8}$

5 As I noted above, Tityrus and Galatea are brought together only in Virgil, Eclogue 1. Below I argue that they form a 'significant' couple. I build my argument progressively, arriving at Virgil through Theocritus, Lucian and the Alexander Romance. ${ }^{9}$ I conclude 
with a discussion of the name 'Tityros' found in Nikos Kazantzakis' autobiography entitled Report to Greco and in his novel KapetánMichális (Freedomor Death).

\section{Гa入áteıa and tupós in Theocritus}

Though Galatea appears already in Homer (Il. 18.45) and Hesiod (Theog. 250), the earliest near-explicit etymology of the name appears much later. According to the historian Douris Polyphemus set up a shrine to Galatea near Etna to honor her for the

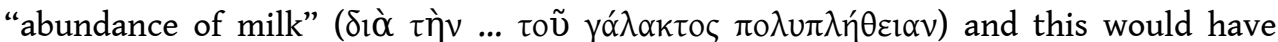
inspired Philoxenus of Cythera, when he visited the place, to invent the story of Polyphemus' love for Galatea (FGrHist $76 \mathrm{~F} 58$ ).$^{10}$ The story is justifiably rejected as an example of the rationalization of myths, ${ }^{11}$ but precisely this feature would make it the first near-explicit etymology of Galatea. The first explicit occurrence appears in the $12^{\text {th }}$ century A.D. It is found in Eustathius' commentary on the above-mentioned Homeric passage (vol. 4, page 135.12-15 Van der Valk). Eustathius mentions that the Nereid $\underline{\Gamma \alpha \lambda \alpha}$

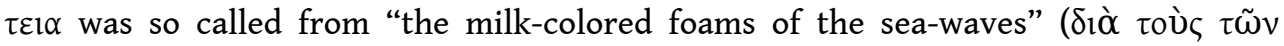

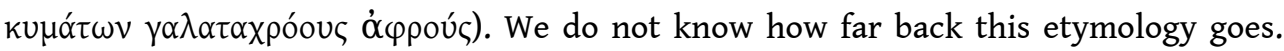
According to the evidence we possess, literary (implied) etymologies of Galatea appear first in Hellenistic poetry and specifically in Theocritus, though he was not the first poet to introduce the Polyphemus-Galatea story but probably Philoxenus of Cythera. The theme was also treated by Callimachus and Bion. ${ }^{12}$ In Hellenistic literature poetry and philology are perfectly coordinated and hence Theocritus' literary etymologies are at the same time the testimony of his erudition. Context, however, makes a great difference in poetry: names acquire or change meaning according to it, with dynamic flexibility and allusiveness that defeat the static and explicit word of philological etymologizing.

7 Theocritus treated the story of Polyphemus and Galatea in Idylls 6 and 11. The poems suggest different etymologies of the Nereid's name. I start with the latter, which is the better-known of the two:

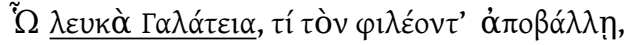

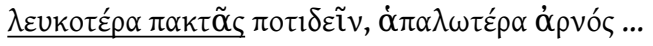

O white Galatea, why do you spurn my love?

whiter than cream cheese, softer than a lamb..

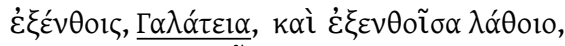

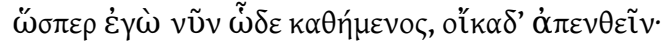

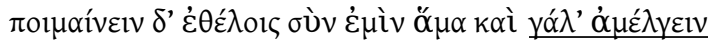

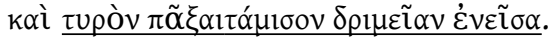

Why don't you come out, Galatea, and when you come out forget,

like me who is sitting here, to go back home?

May you be willing to tend the sheep with me and milk them

and set the cheese putting in sharp rennet.

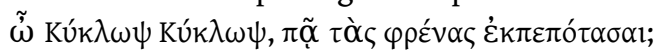

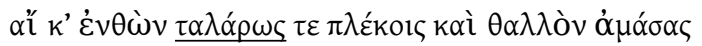

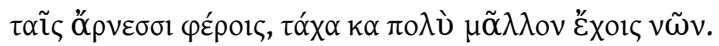

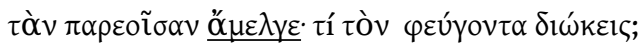

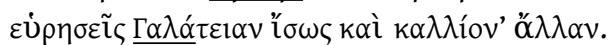

$(11.72-76)$ 
o Cyclops, Cyclops! Where is your sound mind gone?

If you went to weave your baskets or gather shoots

for the lambs, you would show more sense.

Milk the ewe that you have; why chase one that flees from you?

Perhaps you will find another Galatea, even fairer.

8 as he did not understand Odysseus' disguise as Outis", ${ }^{17}$ implying that the Cyclops compares Galatea with cheese while her name suggests milk. In order to clarify this point it is necessary to look at the other occurrences of the name in the poem. It is extremely important that all three occurrences of ' $\Gamma \alpha \lambda \alpha$ ' $\tau \varepsilon 1 \alpha$ ' in the Cyclops' song insert the name in the semantic field of 'milk' ('whiteness', 'milking') and 'cheese'

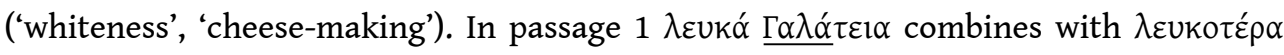

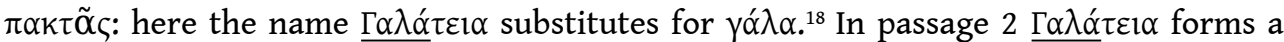

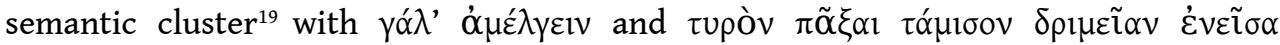
('cheese-making'): the cluster includes both $\underline{\Gamma \alpha} \lambda \alpha$ ' $\tau \varepsilon 1 \alpha$ and $\gamma \alpha \dot{\alpha} \lambda \alpha$. Finally, in passage 3 $\tau \alpha \lambda \alpha ́ \rho \omega \varsigma$ stands for 'cheese-making' (it was a receptacle where milk intended for cheese-making was placed) and combines with ớ $\mu \varepsilon \lambda \gamma \varepsilon$ ('milking') and $\underline{\Gamma \alpha \lambda \alpha ́} \tau \varepsilon 1 \alpha v$ : here

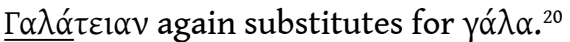

If, therefore, $\Gamma \alpha \lambda \alpha$ q́ $\varepsilon \varepsilon 1 \alpha v$ is consistently exploited in the Cyclops' song to create semantic pairs with 'cheese', this would suggest, in my view, that the Cyclops is aware of the meaning of the name. In Theocritus 11 the Cyclops constructs a ' $\Gamma \alpha \lambda \alpha$ ' $\tau \varepsilon 1 \alpha v$ ' perfectly adapted to his main activity as a shepherd: she is whiter than his dairy products; she is invited to tend the sheep, milk the ewes and make cheese; he would have liked to 'milk' her like a 'ewe', but she is unwilling and so he will have to content himself with 'milking the ewe that he has', one of the girls that have taken a fancy to him. The specific semantic associations of ' $\Gamma \alpha \lambda \alpha ́ \tau \varepsilon 1 \alpha v$ ' occur only in the Cyclops' song and not in the opening section addressed by the poet to Nikias $(8,13)$. Finally, the examination of these passages has confirmed that in all cases the essential semantic pair is 'milk / $\underline{\Gamma \alpha \lambda \alpha}$ $\tau \varepsilon 1 \alpha \nu$ and cheese'. When the pair is thematized, it adapts to different contexts and suggests different things. 'Whiteness' is just one of them.

In Theocritus 6 the name is differently contextualized. Here is the passage:

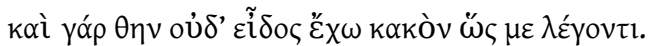

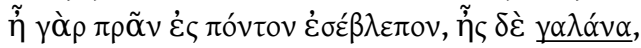

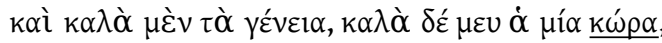

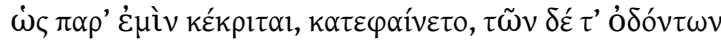

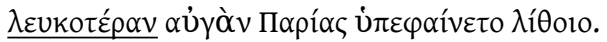

For in truth, I am not as ugly as they say.

Only lately I was looking into the sea, when all was calm, 
and I thought my beard looked beautiful, and so did my one eye,

while my teeth gleamed whiter than Parian marble.

As noted above, in literature the meaning of names is not static but dynamic; it may change within a collection of poems or within the same poem. Richard Hunter sums up the semantics of the present passage as follows: "Whereas in Idyll 11 Polyphemos gazed

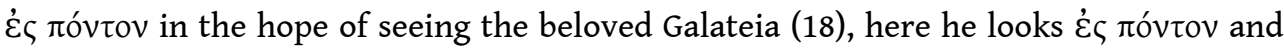

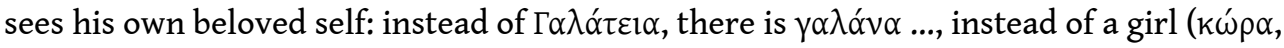
cf. 1.82), there is his eye, $\kappa \omega ́ p \alpha$... In Idyll 11 whiteness was on the side of 'Miss Milky'; now the Cyclops has it". ${ }^{21}$ One has to be reminded that we never hear the voice of Galatea but only the voice of the Cyclops. In other words her name acquires meaning only through him and according to his viewpoint. In Idyll 11 he sees ' $\gamma \alpha$ ' $\lambda \alpha$ ' in her name; here he sees ' $y \alpha \lambda \alpha$ ' $v \alpha$ ', 'calm of the sea', because it is what suits him and specifically

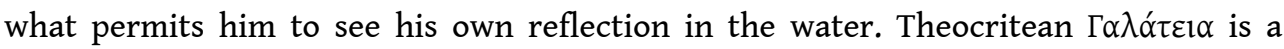
purely mental construction. In other words her name exists only in the Cyclops' fantasy and is shaped according to his mood and love passion or strategy. This is the ground where poetry challenges philology.

Worthy of note is Lucian's commentary on the semantics of ' $\Gamma \alpha \lambda \alpha$ '́⿴囗⿱一兀) and 6. In one of his Marine Dialogues (1.2.11-3.6) the Nereid Doris, who is talking to Galatea, makes the following biting comment about Polyphemus' attraction to her

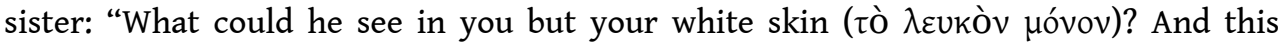

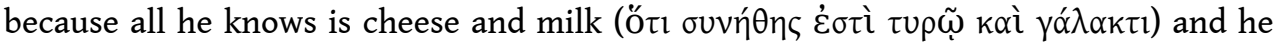
considers everything pretty that is like them. If you want to find out what you really

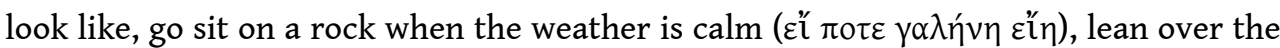

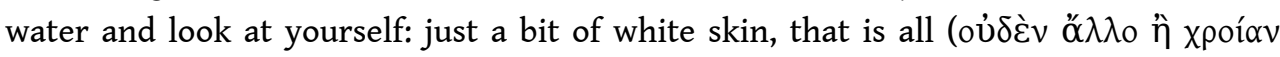

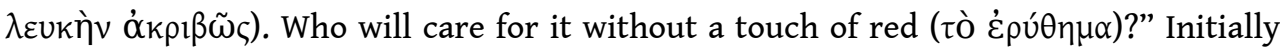

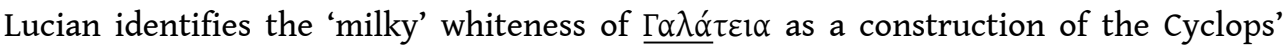
mind. He next adapts the Cyclops' 'gaze in the calm water' ( $\gamma \alpha \lambda \eta$ vn) in order to render the viewpoint of a third party (Doris). The Attic Greek ( $\gamma \alpha \lambda \eta$ nq) makes the play on

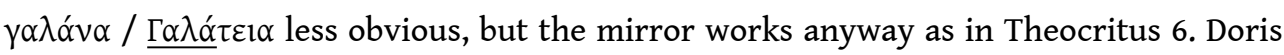
assumes that $\Gamma \alpha \lambda \alpha$ ' $\tau \varepsilon 1 \alpha$ will see in the calm water 'plain whiteness', while in the Cyclops' eyes his own teeth 'shone with a gleam whiter than Parian marble'. The Parian marble comparison would have suited Galatea's body much better than the Cyclops' teeth, but Doris is wicked and makes things worse by adding that white skin alone is not to be appreciated unless accompanied with 'a touch of red'. Galatea's reply is sarcastic: "Well,

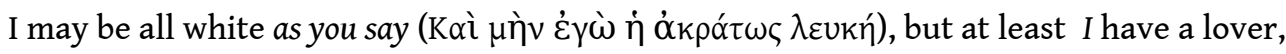
while you have none: not a shepherd, not a sailor, not a ferryman". Galatea neither confirms nor denies her sister's earlier comments; she merely accepts, for the sake of argument, her last disparaging comment about the 'pure whiteness' of her skin and strikes back. Thus Lucian's humorous commentary ends up doing the same thing as the text of Theocritus: it elucidates it and at the same time provides further viewpoints on the 'whiteness' of $\Gamma \alpha \lambda \alpha$ á $\varepsilon 1 \alpha$, which remains invariably context-bound.

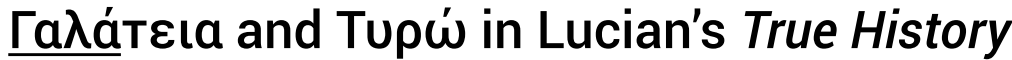

14 I argued above that in Theocritus 11 the essential semantic pair is 'milk / $\Gamma \alpha \lambda \alpha$ q́ $\varepsilon \varepsilon 1 \alpha$ and cheese'. We can now look at a passage where the second member of the pair ('cheese') is also replaced by a proper name. In Lucian's True History the narrator and his 
companions sail to a sea of milk and an island of cheese. The vines on the island produce milk instead of wine; it has a temple dedicated to Galatea and is ruled by Queen Tyro. Here is the ancient passage followed by an English translation:

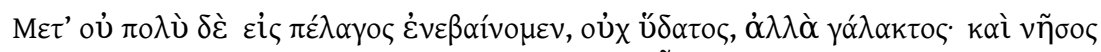

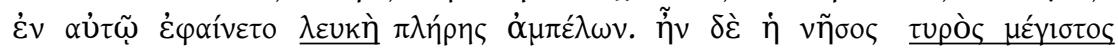

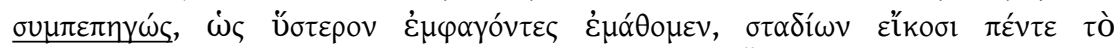

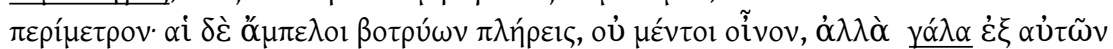

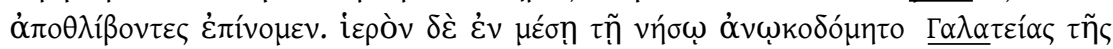

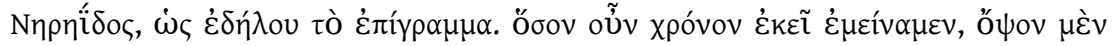

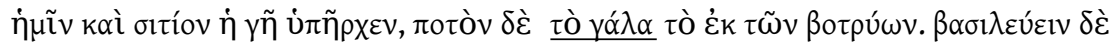

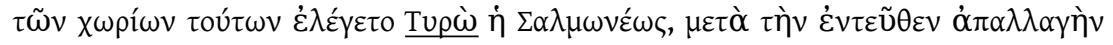

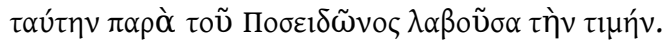

Soon we entered a sea not of water but of milk, in which there was an island, white in color and full of vines. The island was a huge piece of hard cheese, as we later found out by eating it. Its perimeter was twenty-five stades long. The vines were covered with grapes, but when we pressed them we drank not wine but milk. In the middle of the island there was a temple of Galatea the Nereid, as the inscription on it indicated. During the time we stayed there, the ground itself was our bread and meat, and the vine-milk was our drink. We heard that the queen of the place was Tyro, the daughter of Salmoneus, and that Poseidon had given her this honor after death.

The Lucianic passage is sometimes used in combination with the passage from Douris quoted earlier about the shrine Polyphemus dedicated to Galatea (FGrHist 76 F 58), in order to support the existence of a local cult of Galatea. What concerns me in this fantastic description is the pair of significant names $\underline{\Gamma \alpha \lambda \alpha} \tau \varepsilon l \alpha$ and Tupẃ. Obviously Lucian looked for a name that would represent the second member of the semantic pair 'milk and cheese' and found it in Tyro. According to Diodorus Siculus (6.6.5) her name derives from tupóc ('cheese') and she received it "because of the whiteness and softness

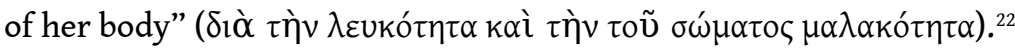

\section{¿átupos and tupós in the Alexander Romance}

In chapter 35 of book 1 the Alexander Romance narrates Alexander's difficult conquest of Tyre. The account contains an oracle and two dreams that foresee the destruction of the city. The second dream has a bearing on this discussion, because it contains an etymology of इá́tupos:

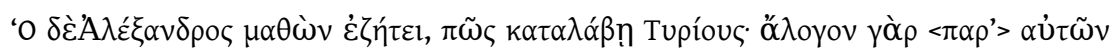

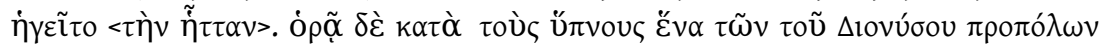

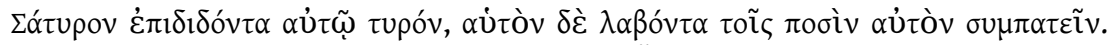

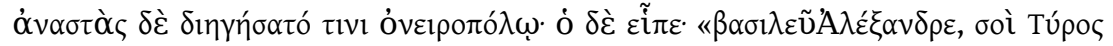

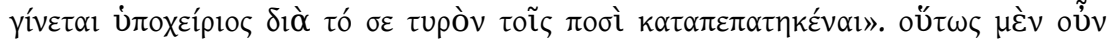

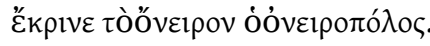

A 1.35.7-8 Stoneman

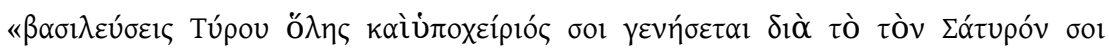

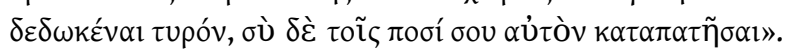

Recension $\beta$ 1.35.7-8 Stoneman

When Alexander heard the news, he began to look for a way to conquer the Tyrians, for he regarded his defeat by them as inconceivable. Then he had a dream: a satyr, one of the attendants of Dionysus was giving him a piece of cheese; he took it and trampled it 
underfoot. When he awoke, he narrated his dream to an interpreter, who told him: "King Alexander, you will bring Tyre under your control, because you trampled the piece of cheese underfoot" [Recension $\beta$ : "You will rule over all Tyre and bring it under your control, because the satyr gave you the piece of cheese and you trampled it underfoot"].

As noted by Stoneman, ${ }^{23}$ in antiquity there were two versions of Alexander's dream.

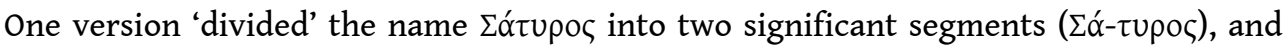

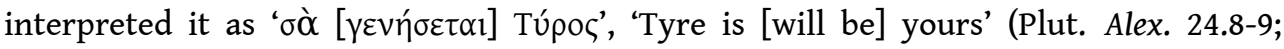
Artemidorus, Oneirocritica 4.24.18-25). The version of the Alexander Romance associates

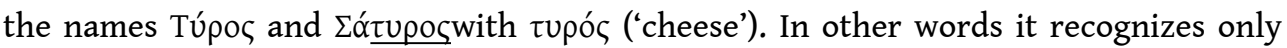
the second segment of $\Sigma$ átupoৎ as etymologically significant.

\section{Tityrus and Galatea in Eclogue 1}

The fact that Tityrus, the name of the character mentioned first in Virgil's Eclogues, was in antiquity identified with a species of Satyr has been noted more than once and brought in connection with the prominent role of Silenus in Eclogue 6 and the 'dancing Satyrs' (saltantis Satyros) in Eclogue 5.73. ${ }^{24}$ If an ancient reader was able to recognize

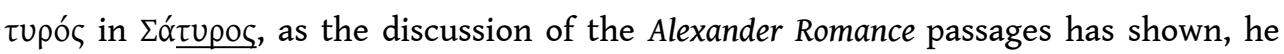
would have obviously been able to do the same in the case of Tityrus. What matters each time is the context in which a proper name is inserted. In my analysis of Polyphemus' song in Theocritus 11 I concluded that the essential semantic pair in the passages where Galatea is mentioned is 'milk and cheese'; that on two occasions $\underline{\Gamma \alpha \lambda \alpha}$ $\tau \varepsilon 1 \alpha$ substitutes for $\gamma \alpha \dot{\alpha} \lambda \alpha$; and that milk and cheese are not employed only as emblems of whiteness. Furthermore, it was seen above that in the Lucianic passage the pair

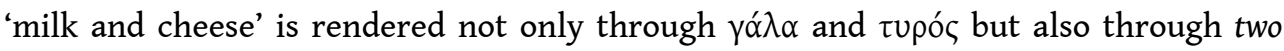

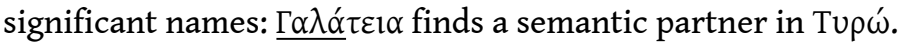

In the context of Eclogue 1.27-35 the semantic pair 'milk and cheese' takes the form ' Galatea / caseus'. Here the female proper name substitutes for 'milk' (lac), exactly as in Theocritus. But this is only the more obvious expression of the pair. Given that the speaker of the lines in question is the only character in the Eclogues that makes cheese

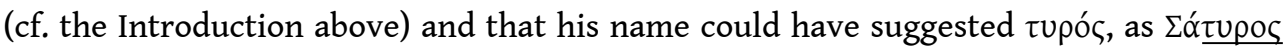
does in the Alexander Romance, the reader cannot but make the semantic connection between Tityrus ('cheese') and Galatea ('milk'). Thus in its full development the semantic pair 'milk and cheese' would turn out to be 'Galatea and caseus / Tityrus'.

From a semantic viewpoint the relationship between Tityrus and Galatea is therefore an expected one. But from an intertextual viewpoint it is one that cannot last, because it is the Virgilian re-writing of the impossible Cyclops-Galatea relationship in Theocritus 11. 'Milk and cheese' play a vital role in both relationships: disdainful $\underline{\Gamma \alpha \lambda \alpha}$ $\tau \varepsilon 1 \alpha$ will not milk the ewes, will not make cheese, will not be 'milked'; enchanting but extravagant Galatea will cause Tityrus to become iners ${ }^{25}$ and will squander the little money he earns by making cheese (no doubt without her help) and selling it to the ungrateful consumers of the neighboring town. Galatea is somehow inserted in the tension between 'town and country', which adapts the sea-land contrast in Theocritus. Virgil's Galatea may have had connections with the town herself (where did the money 
go?). Thus, the difficult Tityrus-Galatea relationship would anticipate the impossible relationship of the next Eclogue, the most famous literary descendant of Theocritus 11.

One final detail concerns the epithet pinguis ('fat') in Ecl. 1.34.Servius thought that it better suited victima in the previous line than caseus; Coleman and others apply it to caseus and understand 'fat cheese' as 'cream-cheese'; Clausen refers it to both 'victim' and 'cheese': "many a fat victim and much fat cheese". There is only one other passage in the Eclogues where pinguis is applied to a 'fat' animal. It occurs in the famous lines of Callimachean inspiration which Apollo addresses to Tityrus in 6.4-5:

'pastorem, Tityre, pinguis

pascere oportet ovis, deductum dicere carmen'

The passage constitutes a striking semantic parallel of 1.33-34: pinguis modifies 'sheep' (ovis), which are prospective (sacrificial) victims as in Eclogue 1; but it simultaneously evokes the meaning rupós in Tityre, forming with the segment -tyre the Greek

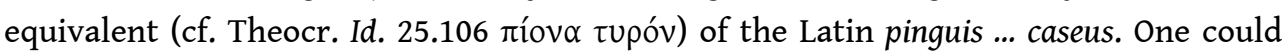
see in this passage a subtextual variation of the ớrò kovvoṽ figure as in Clausen's double application of pinguis in Eclogue 1, but semantic clusters function anyway independently of grammar and syntax. ${ }^{26}$ As regards the semantics of pinguis in its relation with Tityre, I would like to add, purely for the sake of information, that

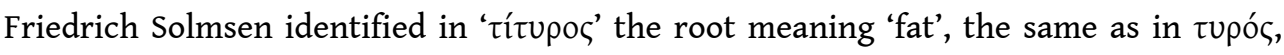
and offered various interpretations of the name. ${ }^{27}$

Virgil did not return to the semantics of 'milk and cheese' in the Eclogues. But the memory of Galatea's 'whiteness' survived in chromatically significant semantic clusters: Galatea ... candidior ... alba (7.37-38);28 and Galatea ... purpureum ... varios ... flores ... candida populus ... umbracula (9.39-42). Since Galatea is in both cases a Nereid, it is possible that her 'whiteness' is also in some way connected with Eustathius' derivation of the name from 'the milk-colored foams of the sea-waves'. Outside the pastoral world the name 'Galatea' may suggest 'shining whiteness' without any obvious reference to

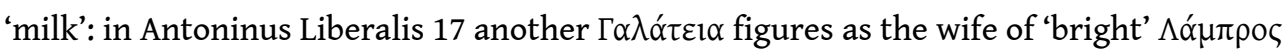
and gives birth to $\Lambda \varepsilon u ́ k ı \pi \pi \circ$, in what is a Greek version of Ovid's story of Iphis (Met. 9.665-796)..$^{29}$

\section{'Milk and cheese' in the Aeneid}

In connection with the etymological association of $\Gamma \alpha \lambda \alpha^{\prime} \tau \varepsilon 1 \alpha$ with sea-foam Richard Hunter observes that "Callimachus uses milk and sea-foam together as examples of

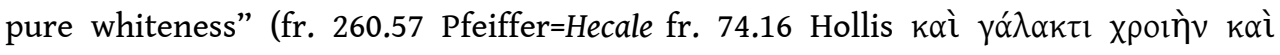

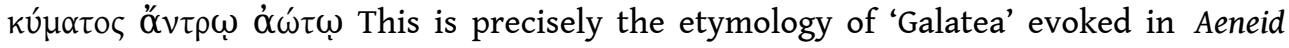
9.102-103: the Nereids Doto and Galatea cleave the 'foaming' waves with their 'breasts' (qualis Nereia Doto / and Galatea secant spumantem pectore pontum). I discussed this semantic cluster in my monograph on Virgil's names, in connection with the milkproducing female breast but also in connection with the transformation of the ships into sea-nymphs: the name Galatea reminds the reader that the besieged Trojans were previously compared to sheep and that Cybele protected the ships like a mother-ewe..$^{30}$

In another chapter of my book entitled the 'Pastoral World of Galaesus, Tyrrhus and Almo' I discussed the pivotal significance of names in the pastoral community of Virgil's Latium (7.531-539). The stag torn from his mother's breast is nurtured by 
Tyrrhus and his two sons, Almo and Galaesus. Tyrrhus is in charge of the king's herds and manages the royal land; Galaesus is the wealthiest man in sheep, cattle, and land in Latium. In a detailed discussion I explained that the name 'Galaesus' suggests $\gamma$ ó $\lambda \alpha$ ('milk') not only in Horace, Odes 2.6.10 (noted by Nisbet-Hubbard, ad loc.) but also in Virgil, Georgics 4.126 and in several passages of Martial (11.22.1, 12.63.3, 5.37.1-2, 4.28.1-4). In the context of Aeneid 7 the 'nurturing' of the stag, the possession of 'cattle' and 'sheep' and other details suggest for 'Almo' and 'Tyrrhus' respectivelythe meanings

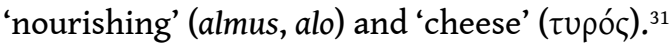

\section{Postscript: Títupos and tupós in Kazantzakis' Report to Greco and Kapetán Michális}

In chapter 5 of his autobiography (Report to Greco) that records his memories from the elementary school,Nikos Kazantzakis introduces Títyros, his second grade teacher:

Títyros reigned over the second grade; he reigned, poor fellow, but did not govern. He was pale, with small eye-glasses, starched shirt, pointed patent leather shoes worn down at heel, a big hairy nose, and slender fingers yellowed from tobacco. His real name was not Títyros; it was Papadákis. But one day his father, who was a priest, brought him from the village a large head of cheese as a present. "What

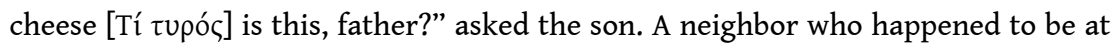
the house heard the question and spread the news. The townspeople began to poke fun at him and gave him the nickname Títupos".

Kazantzakis was a man of vast learning. He probably became acquainted with Latin in the École Commerciale Sainte Croix on the island of Naxos (1897-1899), studied it in the Herakleion Gymnasion (1899-1902) and kept in contact with it as a student at the School of Law of Athens University. As regards Virgil, he was taught the Aeneid in the Gymmasion. His library contains two editions of Virgil's works: C. H. Weise's, Leipzig 1887; and Otto Ribbeck's, in usum scholarum, Leipzig 1889. He probably possessed another copy of Virgil, which he sent to his friend and biographer Pandelís Prevelákis in 1938 but the book never reached him. His letters contain quotations from Virgil, Horace, and other Latin authors. ${ }^{32}$ His deeper acquaintance with the importance of Virgil probably came during the years he was translating Dante's Divine Comedy into Modern Greek. As I have shown elsewhere, the shaping of Alexis Zorbas as a 'guide' of the narrator in Kazantzakis' most famous novel betrays a debt to the figure of Virgil as Dante's afterlife guide in canto 1 of the Inferno. ${ }^{33}$

No copy of Theocritus exists in Kazantzakis' library but in a letter from Vienna he had asked his first wife to send him the Idylls. The library contains, however, a copy of Longus' Daphnis and Chloe. ${ }^{34}$ Kazantzakis was, therefore, undoubtedly aware that Tityrus was a pastoral character and most probably knew it from Virgil's Eclogues. Indirect evidence of his awareness comes from his novel Kapetán Michális (Freedom or Death). In this novel Títyros appears as a fictional character, the brother of Kapetán Michális and a teacher. In chapter 1 the narrator tells briefly the above-mentioned story of the origin of his nickname, which here he attributes to the three malicious spinster sisters of the novel. ${ }^{35}$ In the immediately preceding paragraph he mentions that the same sisters gave Kapetán Michális, the hero of the novel, the nickname "Wild Boar" (Ка́троৎ). 

milk, cheese and meat is very common in Cretan rural communities. So if Kazantzakis knew the meaning 'he-goat', this would make the association of the name with the 'cheese from the village', the pastoral inspiration, and the contrast between 'domestic' (Títyros) and 'wild' (Kapetán Michális) more telling. Whatever the case, in Virgil's Eclogues wild boars stand at the other end of Tityrus' civilized world, dedicated to music-playing, song-making and love. They represent the wild and they are hunted $(3.75,5.76,7.29,5.76)$. Corydon sees in them chaotic nature invading his ordered bucolic life (2.59 liquidis immisi fontibus apros). In pastoral myth the wild boar is primarily known for killing Adonis, whose death is lamented in Theocritus and Bion. opposites. In the opening paragraph Kapetán Michális is said to resemble a wild boar in every respect: the round dark eyes, the protruding canine tooth, his short rigid neck, his heavy, big-boned strength, and above all his rage that knows no barrier. He is a giant in size, feared and respected by Greeks and Turks alike, of unpredictable mood, and unable to control his passions; but he is also a formidable fighter, struggling for the liberation of Crete as well as for personal salvation. These conflicting features make him a highly complex character. In the last paragraph of the book he is found on the mountains of Selena. All his companions have been killed and he is surrounded by the Turks. A Turk throws over to him his nephew's cut off head. He raises it high, having a wild gleam on his face. Then two bullets cut short his cry 'Freedom or [death]'. ${ }^{36} \mathrm{He}$ dies

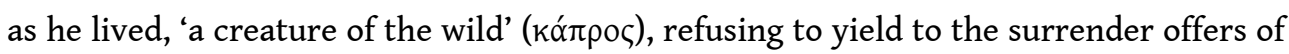
the Turks and to the Greeks who advise him 'in the interest of Crete'.

Kapetán Michális despises learning and education, raises his son with the very same ideals, and feels contempt for men of letters, in particular his brother Títyros and his nephew Kosmás (the latter eventually joins him in the mountains and dies at his side; cf. above). Thus though Títyros is no less devoted to the cause of Cretan liberation than all the others, he is the object of general contempt for the fact of being a teacher

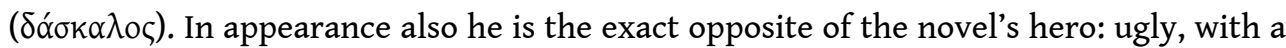
deformed body, and of weak constitution..$^{37} \mathrm{He}$ is deeply despised even by the spinster he marries, who prefers the 'company' of her brother. In the course of the narrative Kapetán Polyksíngis turns the popular association of 'Títyros' with 'cheese' into an emblematic image of the man. According to him, the teacher and Idomenéas (the alter ego of Títyros in the novel) gnaw a hole into their books and nibble, looking like two

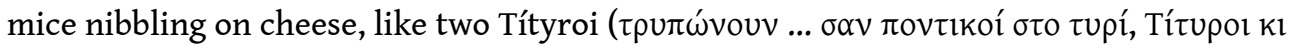

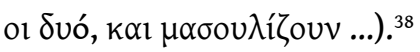

33 The fact that Kazantzakis gave a fictional projection to the popular story about 'Tírupoc' meaning 'What cheese?' may owe nothing to the semantics of Virgil's 'Tityrus' which I presented above. But it nonetheless reveals the vitality of the Greek language and the power of context to generate (new) meaning which science will not see or will not recognize. The competent and experienced reader will no doubt make the connection of Kazantzakis' Títupos with the sátupos of the Alexander Romance, and he may in the end even become willing to recognize 'cheese and milk' in the Virgilian relationship between 'Tityrus and Galatea'. 


\section{BIBLIOGRAPHY}

Beaton 1998: R. Beaton, “Of Crete and Other Demons: A Reading of Kazantzakis's Freedom and

Death", JMGS 16, 195-220

Bömer 1982: Franz Bömer, P. Ovidius Naso: Metamorphosen, Buch XII-XIII, Heidelberg.

Cairns 1999a: Francis Cairns, “Virgil, Eclogue 1.1-2: A Literary Programme?”, HSCP 99 (1999)

289-293.

Cairns 1999b: Francis Cairns, "Ovid Amores 1.15 and the Problematic fruges of Line 25", in Werner Schubert (ed.), Ovid. Werk und Wirkung, Festgabe für Michael von Albrecht zum 65.Geburtstag, Frankfurt am Main, Teil I, 99-109.

Celoria 1992: Francis Celoria, The Metamorphoses of Antoninus Liberalis, London.

Coleman 1977: Robert Coleman (ed.), Vergil: Eclogues, Cambridge.

Diggle 2004: James Diggle (ed.), Theophrastus: Characters, Cambridge.

Du Quesnay 1979: Ian M. le M. Du Quesnay, “From Polyphemus to Corydon”, in D. West and T. Woodman (eds.), Creative Imitation and Latin Literature, Cambridge, 35-69.

Feldherr and James 2004: Andrew Feldherr and Paula James, "Making the Most of Marsyas", Arethusa 37, 75-1003.

Gow 1952: A.S.F. Gow (ed.), Theocritus, vols. I-II, Cambridge.

Hordern 1999: J. H. Hordern, “The Cyclops of Philoxenus”, CQ 49, 445-455.

Hordern 2002: J. H. Hordern, The Fragments of Timotheus of Miletus, Oxford.

Hordern 2004: J. H. Hordern, “Cyclopea: Philoxenus, Theocritus, Callimachus, Bion”, CQ 54, 285-292.

Hunter 1999: Richard Hunter (ed.), Theocritus: A selection, Cambridge.

Lipka 2001: Michael Lipka, Language in Vergil's Eclogues, Berlin / New York.

Maltby 1999: Robert Maltby, “Technical Language in Tibullus”, Emerita 67, 231-249.

Paschalis 1997: Michael Paschalis, Virgil's Aeneid: Semantic Relations and Proper names, Oxford.

Paschalis 2002: Michael Paschalis, review of Andreas Michalopoulos, Ancient Etymologies in Ovid's Metamorphoses: A Commented Lexicon, Leeds, BMCR 2002.10.09.

Paschalis 2007: Michael Paschalis, "The Gestation of Alexis Zorbas and its Four Midwives: Homer, Plato, Dante, and Virgil”, Nea Hestia, Special Issue: Nikos Kazantzakis, December 2007 [in Modern Greek].

Schmidt 1987: Ernst A. Schmidt, Bukolische Leidenschaft oder Über antike Hirtenpoesie, Frankfurt am Main / Bern /New York.

Skutsch 1956: O. Skutsch, “Zu Vergils Eklogen”, RhM 99, 193-200.

Smith 1970: Peter L. Smith, “Vergil's Avena and the Pipes of Pastoral Poetry”, TAPA 101, 497-510.

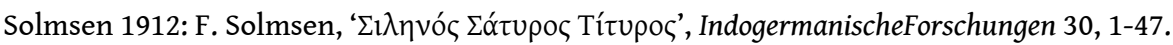

Stamatiou 1983: Yorgos P. Stamatiou, Kazantzakis and the Ancients (Ph.D. Dissertation), Athens 1983 [in Modern Greek]. 
Stoneman 2007: Richard Stoneman (ed.), Il romanzo di Alessandro, vol. I, Trebaseleghe, Padova.

Van Sickle 2000: John B. Van Sickle, "Virgil vs Cicero, Lucretius, Theocritus, Callimachus, Plato, and Homer: Two Programmatic Plots in the First Bucolic", Vergilius 46, 21-58.

Van Sickle 2004: John B. Van Sickle, "Virgil, Bucolics 1.1-2 and Interpretive Tradition: A Latin (Roman) Program for a Greek Genre”, CP 99, 336-353.

Wendel 1914: C. Wendel (ed.), Scholia in Theocritum Vetera, Leipzig.

Wiseman 1988: T. P. Wiseman, “Satyrs in Rome? The Background to Horace's Ars Poetica", JRS 78, 1-13.

Wright 1983: James R. G. Wright, “Virgil’s Pastoral Programme: Theocritus, Callimachus and Eclogue I", PCPS 29, 107-158.

Wüst 1937: Ernst Wüst, “Tityroi”, RE VI.2A, 1609-1611

\section{NOTES}

1. Paschalis 1997, 264.

2. Maltby 1999, 232-237. The only other reference to cheese-making in Virgil occurs in Georg. 3.400-403.

3. On the technical aspect of Corydon's claim cf. Du Quesnay 1979, 65.

4. See Wüst 1937; Smith 1970; Lipka 2001, 182-183; Diggle 2004, 239-241.

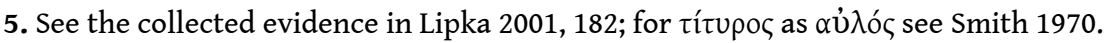

6. Cairns 1999a; Van Sickle 2004; cf. Van Sickle 2000.

7. Coleman 1977, 71; Wright 1983, 108; Smith 1970, 506-507; see also Skutsch 1956, 200; Schmidt 1987, 31-35. Lipka 2001, 183 argues that in the Virgilian passage the name 'Tityrus' stands for the 'amateur's bungling' and not for the 'skilful and pleasant player'.

8. Cairns 1999b, 104.

9. I have selected the most conspicuous cases for my argument. For Galatea in Ovid's Metamorphoses see Paschalis 2002.

10. FGrHist 76 F 58. On Philoxenus see immediately below.

11. See Hordern 1999, 447.

12. Hordern 1999 and 2004. Cf. Hordern 2002, 106-110 on Timotheus' Cyclops (the fragment that survives does not contain a reference to Galatea).

13. On the meaning of $\pi \alpha k \tau$ ó see Gow 1952, ad loc.

14. Frisk and Chantraine, the two major etymological dictionaries of Ancient Greek, do not discuss the name; cf. Bömer 1982, 407-408; Hordern 1999, 447.

15. See in general Paschalis 1997, Introduction.

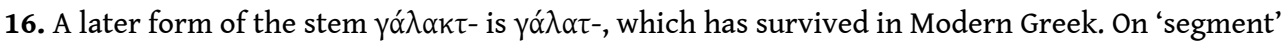
as an arbitrary semantic unit not recognized by morphology see Paschalis 1997, 5.

17. Hunter 1999, 230.

18. On proper names as substitutable semantic units see Paschalis 1997, 4.

19. Paschalis 1997, 5; cf. Paschalis 2002.

20. On the technical terms see Gow 1952 and Hunter 1999, ad loc.

21. Hunter 1999, 257-258.

22. Cf. also $\Sigma$ Hom. Od. 11.235 .

23. 2007, 552 .

24. Recent mentions are found in Wiseman 1988, 10; Feldherr and James 2004, 81.

25. On this point see Wright 1983, 132-133. 
26. Paschalis 1997, 4-5.

27. Solmsen 1912, 34; cf. Wüst 1937, 1609.

28. The cluster 'responds' to lactis ... marmoreum ... aureus (7.33-36, lines spoken by Thyrsis), which contains 'milk'. The dialogue may be significant, but the matter calls for further investigation.

29. Cf. Celoria 1992, 152.

30. Paschalis 1997, 308 and $377-379$.

31. Paschalis 1997, 264.

32. Stamatiou 1983, 48-51, 63; cf. 138, 203.

33. Paschalis 2007.

34. Stamatiou 1983, 56, 66.

35. The novel (1953) precedes the Report to Greco, which was published posthumously (1960).

36. Beaton 1998, 208 observes that the two bullets that are shot respectively through Kapetán Michális' mouth and temples repeat the pattern of the Cross.

37. Compare the description given above of the real Títyros in the Report to Greco.

38. I skip the part that has to do with the development of the character of Títyros in the novel.

\section{ABSTRACTS}

Tityrus and Galatea are found together only in Virgil, Eclogue 1. The article argues that they form a 'significant' pair of pastoral names, suggesting 'cheese' and 'milk'. It provides evidence from Theocritus, where 'milky' Galatea is inserted in the semantic field of 'milk and cheese'; Lucian, where Galatea forms a pair with the proper name Tyro; and the Alexander Romance, where Satyros is etymologized from 'tyros' ('cheese'), in light of the fact that Virgil's 'Tityrus' indicates a species of satyr. The article treats also proper name versions of 'milk and cheese' in the Aeneid. It is concluded with a discussion of the name 'Tityros' found in Nikos Kazantzakis' autobiography entitled Report to Greco and in his novel KapetánMichális (Freedomor Death).

\section{INDEX}

Mots-clés: Virgil, Eclogue 1, Tityrus, Galatea, Theocritus, milk, cheese, Lucian, Tyro, Alexander Romance, Tyre, satyros, Kazantzakis, Tityros, Report to Greco, Freedom or Death 